\title{
Radiation Risk Assessment on Public in Motijheel Thana, Dhaka, Bangladesh
}

\author{
Mohammed Belayet Hossain ${ }^{1}$, M. S. Rahman ${ }^{2 *}$, Mohammad Amir Hossain \\ Bhuiyan $^{3}$, S. Yeasmin 4 \\ ${ }^{1,3}$ Department of Environmental Science, Jahangirnagar University, Dhaka-1342, BANGLADESH \\ ${ }^{* 2,4}$ Health Physics Division, Atomic Energy Centre, Shahbag, Dhaka-1000, BANGLADESH \\ *(msrahman74@gmail.com)
}

This journal is licensed under a Creative Commons Attribution-Noncommercial 4.0 International License (CC-BY-NC). Articles can be read and shared for noncommercial purposes under the following conditions:

- BY: Attribution must be given to the original source (Attribution)

- NC: Works may not be used for commercial purposes (Noncommercial)

This license lets others remix, tweak, and build upon your work non-commercially, and although their new works must also acknowledge you and be non-commercial, they don't have to license their derivative works on the same terms.

License Deed Link: http://creativecommons.org/licenses/by-nc/4.0/

Legal Code Link: http://creativecommons.org/licenses/by-nc/4.0/legalcode

$A B C$ Research Alert uses the CC BY-NC to protect the author's work from misuse.

\section{Abstract}

Objective: The pollution free environment is required for healthy life. The real-time radiation monitoring is very important for radiation hazard detection in the environment. The excess life-time cancer risk (ELCR) on public is to assess based on the real-time radiation monitoring data in the area. Methods: The real-time radiation monitoring was performed using portable digital radiation monitoring device. This real-time digital portable radiation monitoring device meets all European CE standards as well as the American "FCC 15 standard". The real-time digital portable radiation monitoring device was placed at 1 meter above the ground on tripod and data collection time for each monitoring point (MP) was 1 hour. 27 MPs were chosen for collection of real-time radiation data at various outdoor environment in Motijheel Thana, Dhaka from May-August 2018.

Results: The real-time radiation dose rates at Motijheel Thana due to natural radionuclides were ranged from $0.095 \pm 0.041 \mu \mathrm{Sv} \cdot \mathrm{h}^{-1}$ to $0.185 \pm 0.042 \mu \mathrm{Sv} \cdot \mathrm{h}^{-1}$ with an average of $0.147 \pm 0.047 \mu \mathrm{Sv} \cdot \mathrm{h}^{-1}$. The annual effective dose to public from outdoor environmental radiation at Motijheel Thana were found to be $0.166 \pm 0.066 \mathrm{mSv}$ to $0.324 \pm 0.061 \mathrm{mSv}$ with an average of $0.257 \pm 0.039 \mathrm{mSv}$. Excess Life-time Cancer Risk (ELCR) on public are also estimated based on annual effective dose that is ranged from $0.662 \times 10^{-3}$ to $1.289 \times 10^{-3}$ with an average value of $1.025 \times 10^{-3}$, which is higher than world average value of $0.29 \times 10^{-3}$

Conclusion: This type of study is required for detection of the radiation hazard arising from the natural as well as man-made sources and also for generation of the baseline database. From this study, it is observed that there is no pose any radiation hazard in the study area due to man-made sources.

\section{Keywords}

Radiation, Outdoor environment, In-Situ, Public, Cancer.

\section{INTRODUCTION}

Public are being exposed to ionizing radiation at the outdoor environment that comes from both the natural and the artificial radionuclides. Normally, about $85 \%$ of the annual total radiation dose of public arises from the natural radionuclides of both terrestrial and cosmogenic origin (Belivvermis M. et al., 
2010). Radiation exposure to extraterrestrial source, galactic cosmic rays and energetic particles from lunar particle events depends mainly on geological characteristics of a place such as altitude, latitude and stellar activity (ATSDR, 1999), (UNSCEAR, 2000). One of the major external sources of ionizing radiation to the public is contributed by the gamma radiation emitted by naturally occurring radioisotopes from the terrestrial origin. The most prominent gamma emitting naturally occurring radioisotopes are ${ }^{40} \mathrm{~K}$ and the radionuclides from the ${ }^{232} \mathrm{Th}$ and ${ }^{238} \mathrm{U}$ series with their decay products that exist very small amount in all ground formations.

In the last few decades, various studies have been performed throughout the world to assess activity concentration and dose rate due to the terrestrial gamma radiation (Wilson, 1994), (H.L. Beck et al., 1972). High difference has been reported to other international authors (Al-Ghorable FH, 2005), (Arvela H, 2002), (Rybach L, 2002), (Sagnatchi F, 2008), (Tavakoli MB, 2003) for highly penetrating gamma radiation dose rates at the outdoor and indoor environment. In situ gamma spectroscopy and dose rate monitoring using portable digital radiation monitoring devices are very popular worldwide because large area radiation monitoring is possible within the shortest period of time. Both laboratory and In-situ gamma spectroscopy are often used for monitoring and estimating of activity concentration and radiation dose rates at the outdoor and indoor environment due to both natural and man-made radionuclides (QUARTO M. et al., 2013), (AL-SALEH, 2007).

Measurement of the activity concentration contributing from the gamma radiation and characterizing its radionuclides with gamma spectroscopy have been utilized effectively at the outdoor environment through In-Situ Method (CLOUVAS A. et al., 2004), (E. Svoukis et al., 2006). Public get radiation exposure from the external sources of ionizing radiation and internal sources of ionizing radiation. The external exposure to public resulting from the soil, rock, water, granite, construction materials of the buildings, etc. The internal exposure to public resulting from the ingestion and inhalation pathways. The estimation of the radiation risk on public resulting from the radiation emitted by natural $\&$ artificial radionuclides is crucial as these radionuclides contribute to the collective dose of the public (UNSCEAR, 1982). The In-situ radiation dose rate monitoring is very reliable at the indoor and outdoor environments (HAZRATI S. et al., 2010), (J. F. B. Ateba et al., 2010).

Many advanced countries with well-developed health care system, medical radiation exposures are now the significant single source of ionizing radiation (UNSCEAR, 2008). Since ionizing radiation is pose harm to public, care should be taken for protection of the public and the environment from hospital radiation sources. Radiation exposure to patients during radiographic examination (computerized tomography, fluoroscopic procedures, dental diagnosis, and routine exposure to X-rays), radioisotope procedures and radiation therapy have contributed to raise the background radiation level and many radiation workers (NCRP Report No. 160, 2009).

Motijheel Thana is the main commercial area of Bangladesh and population 2,25,999 (male 1,33,151 and female 92,848) (Bangladesh population Census, 2011). Several large establishments such as Bangladesh Bank, Government \& Private bank's headquarters, Banga Bhaban (President's House), National mosque nearby, Bangladesh Secretariat nearby, Soccer \& hockey stadiums, famous educational institutions like Notre Dame college, motijheel ideal school \& college, etc. and many government \& private offices such as Dhaka Stock Exchange, Biman Bangladesh Air lines, Bangladesh Chemical Industries, Bangladesh Jute Industries Corporation, Water and Power Development Board and Rajuk Bhaban, etc., many shopping mall in \& around like Gulistan Market, etc. are situated in the Motijheel Thana.

Therefore, many people used to visit the Motijheel Thana area from all over the country. The objective of the study is to monitor the outdoor environmental radiation dose rate at Motijheel Thana area in Dhaka city and to estimate the excess life-time cancer risk (ELCR) on public based on the real-time radiation monitoring data. 
MATERIALS AND METHODS

\section{Description of the equipment}

A real-time digital portable radiation monitoring device which is known as Gamma-Scout was used for the study. Gamma-Scout is German designed, and manufactured by GmbH Co. \& KG (Germany), built with a solid Novadur exterior. An optional stylish leather holster with belt strap can further protect the Gamma-Scout from the elements. The Gamma-Scout meets all European CE standards as well as US FCC 15. All units come with an industry leading 2-year manufacturer's warranty and a serialized test certificate. The Gamma-Scout is a fully featured Geiger counter with a form fitting ergonomic shape. The unit has a battery indicator, multiple unit conversion, real-time dose rate and cumulative dose display functions and programmable logging and alert functions.

Advanced functions include PC data download via USB cable and an ultra-low current power circuit for extended battery life (User Manual-GAMMA SCOUT, 2014). The real-time radiation monitoring was carried out at 27 selected locations of Motijheel Thana using the Gamma-Scout from May-August 2018. The Gamma- Scout was placed on tripod at 1 meter height and time for radiation dose rate monitoring was $1 \mathrm{~h}$ for each location. The location was identified using Garmin eTrex GPS device. This device has rugged handheld GPs with enhanced capabilities.

The device has 2.2 inches monochrome display and so easy to read in any light. The device has GPS and GLONASS satellites for faster positioning, 25-hour battery life with 2 AA batteries. The device is durable and water resistance, eTrex device is built for withstand the elements. It is very easy to use interface means one can spend more time at outdoor and less time searching for information. The device is environment friendly, dust, dirty, humidity water-none are a match for this navigator. Garmin eTrex device stores and displays key information including location, terrain, difficulty, hints and descriptions which means no more manually entering coordinates and paper printouts. Fig. 1 shows the location of Motijheel Thana in Dhaka city where outdoor environmental radiation monitoring was performed using a digital portable radiation monitoring device through In-situ method. Table 1 depicts the description of radiation monitoring location.

\section{Description of the area}

The study locations were identified using GARMIN eTrex HC series personal navigator. The unit uses the proven performance of Garmin high-sensitivity GPS and full-featured mapping to create an unsurpassed portable GPS receiver (Owner's Manual-GARMIN eTrex HC Series, 2007). The study area is located from E90 $24366^{\prime} .18^{\prime \prime}$ to E90 $25^{\prime} 38.34^{\prime \prime}$ and from $\mathbf{N} 23^{\circ} 43^{\prime} 18.45^{\prime \prime}$ to $\mathbf{N} 23^{\circ} 44^{\prime} 38.16^{\prime \prime}$ and in this area 27 locations were selected for measurement of outdoor environmental radiation dose rates at Motijheel Thana in Dhaka city. Motijheel Thana area is 3.69 sq. km, located in between $23^{\circ} 43^{\prime}-23^{\circ} 44^{\prime}$ north latitudes and $90^{\circ} 24^{\prime}-90^{\circ} 25^{\prime}$ east longitudes. Total population 2,25,999 (male: 1,33,151 and female: 92,848), population density 61,246/sq.km (Bangladesh Bureau of Statistics, 2011). Motijheel Thana is the main commercial area of Bangladesh and many high-rise buildings were located in the area. Motijheel Thana area is the busiest area of Dhaka city, because many Head Offices of the government \& Private Organizations are situated in the Motijheel Thana.

\section{Data collection technique and equation for dose estimation}

Real-time outdoor environmental radiation dose rate was monitored at the area of Motijheel Thana in Dhaka city. The real-time radiation monitoring was carried out using a digital portable radiation monitoring device from May-August 2018. The digital portable radiation monitoring device was placed at 1 meter above the ground on tripod and data collection time for each location was $1 \mathrm{~h}$. Total 27 locations at the outdoor environment of Motijheel Thana area were selected for collection of the realtime radiation dose rates as shown in the map of the Motijheel Thana (Banglapedia, 2021) Fig. 1. The locations were identified using Garmin eTrex GPS device as shown in Table 1. 


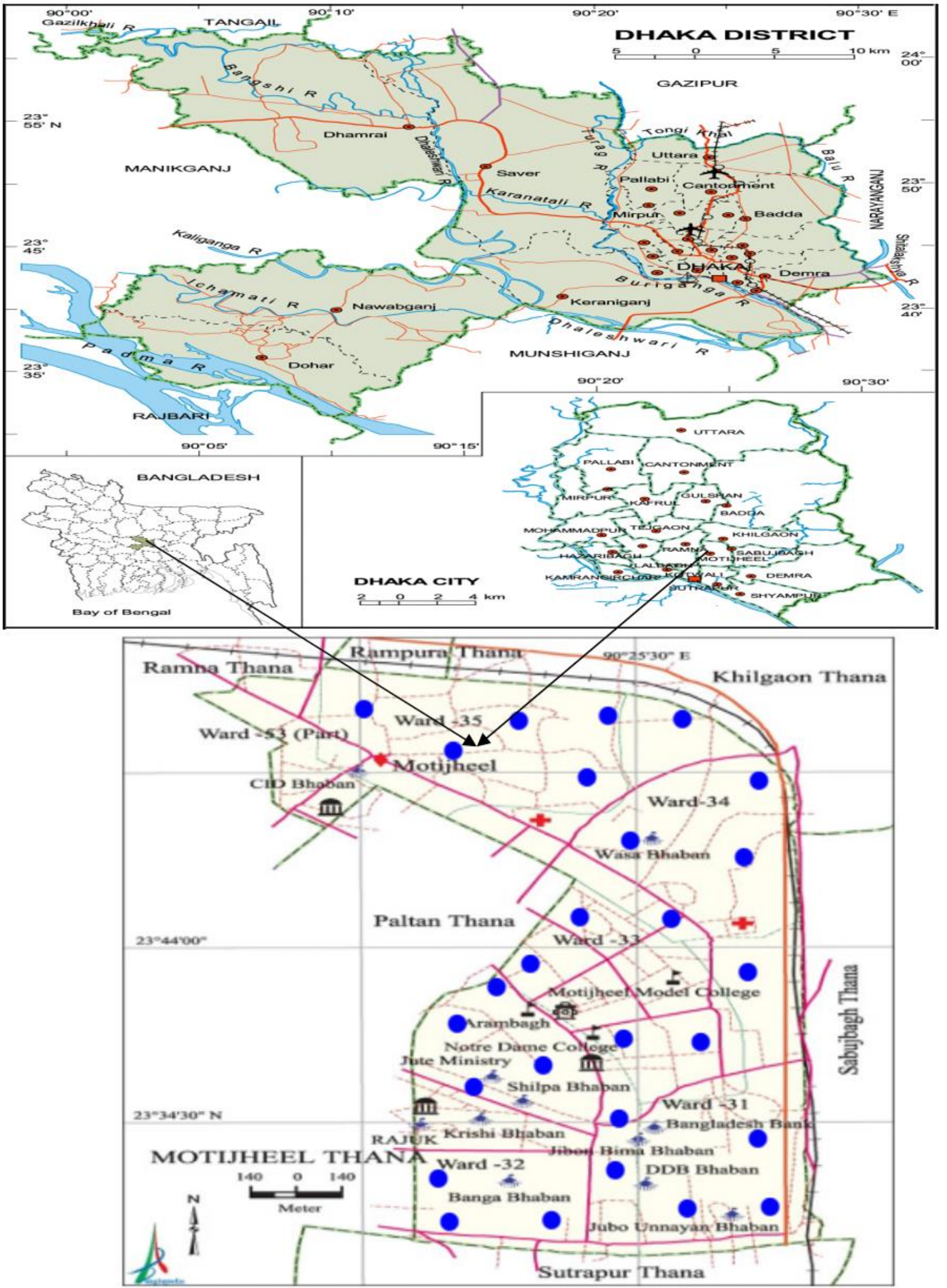

Fig.1: Shows the location $(\bullet)$ of the Motijheel Thana area in Dhaka city where real-time radiation monitoring was performed at outdoor environment. 
United Nations Scientific Committee on the Effects of Atomic Radiation (UNSCEAR) 1988 (UNSCEAR, 1988) recommended the outdoor \& indoor occupancy factor of $0.20 \& 0.80$ for public respectively. These occupancy factors are the proportion of the total time during which an individual is exposed to a radiation field at outdoor \& indoor. The indoor \& outdoor annual effective doses to public due to radiation are estimated using the following equations:

Outdoor annual effective dose $(\mu \mathrm{Sv})=$ dose rate $\left(\mu \mathrm{Sv} \cdot \mathrm{h}^{-1}\right) \times 0.2 \times 8760 \mathrm{~h} \cdot \mathrm{yr}^{-1}$

Indoor annual effective dose $(\mu \mathrm{Sv})=\operatorname{dose}$ rate $\left(\mu \mathrm{Sv} \cdot \mathrm{h}^{-1}\right) \times 0.8 \times 8760 \mathrm{~h} \cdot \mathrm{yr}^{-1}$

\section{Excess lifetime cancer risk (ELCR)}

Excess life-time cancer risk (ELCR) on public is estimated using the following equation:

$$
E L C R=A E D \times D L \times R F
$$

Where AED is annual effective dose to public, DL is the duration of life of Bangladeshi people and was taken from the website (http://en.worldstat.info/Asia/Bangladesh, 2021) and RF is the risk factor $\left(\mathrm{Sv}^{-1}\right)$, it is a fatal cancer risk per Sievert. For stochastic effects from low dose radiation, ICRP 103 suggested the value of 0.057 for the public exposure (ICRP, 2007).

\section{RESULTS AND DISCUSSION}

\section{Real-time dose rate and annual effective dose}

The real-time radiation dose rates at the outdoor environment of the Motijheel Thana area due to natural radionuclides were ranged from $0.095 \pm 0.041 \mu \mathrm{Sv} \cdot \mathrm{h}^{-1}$ to $0.185 \pm 0.042 \mu \mathrm{Sv} \cdot \mathrm{h}^{-1}$ with an average of 0.147

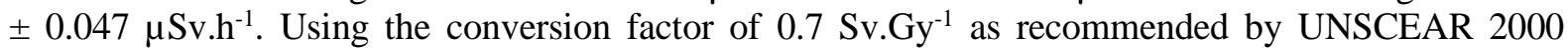
(UNSCEAR, 2000) and considering that people in Bangladesh spend approximately $20 \%$ of their time outdoor and remaining $80 \%$ of time indoor.

The annual effective dose on public was calculated based on the assumption (UNSCEAR, 2000) in Dhaka city due to the outdoor environmental radiation is given in Table 1 . The annual effective dose on public due to the outdoor environmental radiation was also estimated and ranged from $0.166 \pm 0.066$ $\mathrm{mSv}$ to $0.324 \pm 0.061 \mathrm{mSv}$. The average annual effective dose was found to be $0.257 \pm 0.039 \mathrm{mSv}$. The real-time outdoor environmental radiation and radioactivity monitoring is very important for detection of the anthropogenic radionuclides releasing (if any) from the nuclear (NPP, research reactor, etc.) and radiological (hospital, etc.) facilities of the country or from neighboring countries.

The real-time radiation monitoring is also important to generate the baseline database from natural sources before starting operation of the country's first nuclear power plant (Rooppur NPP). The national baseline database is very important for comparison before and after operation of the nuclear power plant. There are many diagnostic centres and few hospitals are situated in and around the Motijheel Thana area and many residential buildings are situated nearby those diagnostic centres and hospitals.

Therefore, this type of study is needed to know the radiation burden on environment and public from those diagnostic centres and hospitals. Continuous radiation monitoring is required for the protection of the environment and the public from unnecessary radiation hazard.

\begin{tabular}{|c|c|c|c|c|c|c|}
\hline \multirow{2}{*}{$\begin{array}{c}\text { Sl } \\
\text { No } \\
\text {. }\end{array}$} & \multirow[t]{2}{*}{ Name of Place } & \multirow[t]{2}{*}{$\begin{array}{l}\text { Latitude/ } \\
\text { Altitude }\end{array}$} & \multicolumn{3}{|c|}{$\begin{array}{c}\text { Radiation dose rate } \\
\left(\mu \mathrm{Sv} \cdot \mathrm{hr}^{-1}\right)\end{array}$} & \multirow{2}{*}{$\begin{array}{c}\text { Mean annual } \\
\text { effective dose } \\
\text { due to } \\
\text { radiation } \\
(\mathrm{mSv}) \pm \mathrm{SD} \\
\end{array}$} \\
\hline & & & Range & Mean & SD & \\
\hline 1 & $\begin{array}{l}\text { BDBL Bhaban, } 8 \text { DIT } \\
\text { Avenue }\end{array}$ & 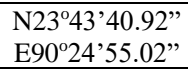 & $\begin{array}{l}(0.04- \\
0.22)\end{array}$ & 0.132 & 0.056 & $0.233 \pm 0.068$ \\
\hline
\end{tabular}




\begin{tabular}{|c|c|c|c|c|c|c|}
\hline 2 & NSC Tower & $\begin{array}{l}\text { N234' } 46.38^{\prime \prime} \\
\text { E90 } 24^{\prime} 51.12^{\prime \prime}\end{array}$ & $(0.09-0.2)$ & 0.145 & 0.036 & $0.254 \pm 0.074$ \\
\hline 3 & $\begin{array}{l}\text { Banga Bhaban, } 61 \\
\text { Dilkusha C/A }\end{array}$ & $\begin{array}{l}\text { N234'33.30" } \\
\text { E90'25'01.04" }\end{array}$ & $(0.08-0.2)$ & 0.140 & 0.038 & $0.245 \pm 0.063$ \\
\hline 4 & $\begin{array}{l}\text { Banga Bhaban, Gate } \\
\text { No.5, Near Ettefaq } \\
\text { Point }\end{array}$ & $\begin{array}{l}\mathrm{N} 23^{\circ} 43^{\prime} 18.45^{\prime \prime} \\
\mathrm{E} 90^{\circ} 25^{\prime} 13.70^{\prime \prime}\end{array}$ & $\begin{array}{l}(0.12- \\
0.25)\end{array}$ & 0.185 & 0.041 & $0.324 \pm 0.068$ \\
\hline 5 & $\begin{array}{l}\text { Bangladesh Bank, } \\
\text { Head Office }\end{array}$ & $\begin{array}{l}\mathrm{N} 23^{\circ} 43^{\prime} 34.80^{\prime \prime} \\
\mathrm{E} 90^{\circ} 25^{\prime} 18.72^{\prime \prime}\end{array}$ & $\begin{array}{l}(0.05- \\
0.19)\end{array}$ & 0.120 & 0.048 & $0.210 \pm 0.065$ \\
\hline 6 & $\begin{array}{l}\text { Baitul Mukarram } \\
\text { National Mosque }\end{array}$ & $\begin{array}{l}\mathrm{N} 23^{\circ} 43^{\prime} 47.59^{\prime \prime} \\
\mathrm{E} 90^{\circ} 24^{\prime} 44.36^{\prime \prime}\end{array}$ & $\begin{array}{l}(0.09- \\
0.21)\end{array}$ & 0.148 & 0.037 & $0.260 \pm 0.053$ \\
\hline 7 & $\begin{array}{l}\text { Modhumita } \\
\text { Cinema Hall, } \\
\text { 158-160 Motijheel }\end{array}$ & $\begin{array}{l}\text { N234' } 23.40^{\prime \prime} \\
\text { E90'25'18.66" }\end{array}$ & $(0.05-0.3)$ & 0.158 & 0.067 & $0.277 \pm 0.071$ \\
\hline 8 & GPO, Gulistan & $\begin{array}{l}\text { N234' } 40.86^{\prime \prime} \\
\text { E90'24'38.82”' }\end{array}$ & $\begin{array}{l}(0.07- \\
0.24)\end{array}$ & 0.137 & 0.047 & $0.241 \pm 0.068$ \\
\hline 9 & $\begin{array}{l}\text { Fars Hotels \& Resorts, } \\
\text { Bijoy Nagar }\end{array}$ & 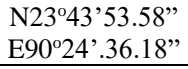 & $\begin{array}{l}(0.05- \\
0.38)\end{array}$ & 0.156 & 0.086 & $0.274 \pm 0.058$ \\
\hline 10 & Scout Bhaban & $\begin{array}{l}\text { N234' } 14.82^{\prime \prime} \\
\text { E90'24'36.78" }\end{array}$ & $\begin{array}{l}(0.02- \\
0.24)\end{array}$ & 0.158 & 0.060 & $0.277 \pm 0.063$ \\
\hline 11 & $\begin{array}{l}\text { Polwell Super Market } \\
\text { Near Jonaki Cinema } \\
\text { Hall }\end{array}$ & $\begin{array}{l}\mathrm{N} 23^{\circ} 44^{\prime} 09.60^{\prime \prime} \\
\mathrm{E} 90^{\circ} 24^{\prime} 54.54^{\prime \prime}\end{array}$ & $\begin{array}{l}(0.05- \\
0.19)\end{array}$ & 0.124 & 0.043 & $0.218 \pm 0.159$ \\
\hline 12 & $\begin{array}{l}\text { Notre Damm College } \\
\text { Gate }\end{array}$ & $\begin{array}{l}\text { N234' } 52.98^{\prime \prime} \\
\text { E90 } 25^{\prime} 16.38^{\prime \prime}\end{array}$ & $\begin{array}{l}(0.09- \\
0.23)\end{array}$ & 0.160 & 0.044 & $0.280 \pm 0.075$ \\
\hline 13 & $\begin{array}{l}\text { Kamalapur Railway } \\
\text { Station }\end{array}$ & $\begin{array}{l}\text { N234' } 56.52^{\prime \prime} \\
\text { E90'25'32.82” }\end{array}$ & $\begin{array}{l}(0.08- \\
0.27)\end{array}$ & 0.160 & 0.056 & $0.281 \pm 0.047$ \\
\hline 14 & $\begin{array}{l}\text { Kamalapur Railway } \\
\text { Hospital }\end{array}$ & $\begin{array}{l}\text { N234'10.74' } \\
\text { E90 } 25^{\prime} 24.96^{\prime \prime}\end{array}$ & $\begin{array}{l}(0.08- \\
0.22)\end{array}$ & 0.145 & 0.043 & $0.255 \pm 0.088$ \\
\hline 15 & $\begin{array}{l}\text { Bangladesh Police } \\
\text { Liberation War Mu- } \\
\text { seum }\end{array}$ & $\begin{array}{l}\text { N234'20.76"' } \\
\text { E90'25'09.66" }\end{array}$ & $(0.06-0.2)$ & 0.130 & 0.044 & $0.228 \pm 0.065$ \\
\hline 16 & Hosaf Tower Malibag & $\begin{array}{l}\text { N23 } 44^{\circ} 38.16^{\prime \prime} \\
\text { E90'24'52.50" }\end{array}$ & $\begin{array}{l}(0.08- \\
0.24)\end{array}$ & 0.152 & 0.049 & $0.267 \pm 0.073$ \\
\hline 17 & City Heart, Motijheel & $\begin{array}{l}\text { N234' } 44.16^{\prime \prime} \\
\text { E90 } 25^{\prime} 02.82^{\prime \prime}\end{array}$ & $\begin{array}{l}(0.03- \\
0.16)\end{array}$ & 0.095 & 0.041 & $0.166 \pm 0.095$ \\
\hline 18 & $\begin{array}{l}\text { Arambaag Playing } \\
\text { Ground }\end{array}$ & $\begin{array}{l}\text { N234' } 42.48^{\prime \prime} \\
\text { E90 } 25^{\prime} 10.08^{\prime \prime}\end{array}$ & $\begin{array}{l}(0.05- \\
0.18)\end{array}$ & 0.115 & 0.041 & $0.201 \pm 0.078$ \\
\hline 19 & $\begin{array}{l}\text { Mohammedan Sport- } \\
\text { ing Club }\end{array}$ & $\begin{array}{l}\text { N234' } 40.68^{\prime \prime} \\
\text { E90 } 25^{\circ} 13.74^{\prime \prime}\end{array}$ & $(0.1-0.25)$ & 0.170 & 0.045 & $0.299 \pm 0.073$ \\
\hline 20 & $\begin{array}{l}\text { Bangladesh Bank } \\
\text { Nibash, RK Mission } \\
\text { Road, Dhaka-1203 } \\
\end{array}$ & $\begin{array}{l}\mathrm{N} 23^{\circ} 43^{\prime} 22.86^{\prime \prime} \\
\mathrm{E} 90^{\circ} 25^{\prime} 20.16^{\prime \prime}\end{array}$ & $(0.1-0.27)$ & 0.178 & 0.052 & $0.312 \pm 0.090$ \\
\hline 21 & $\begin{array}{l}\text { Rupali Bank Training } \\
\text { Academi, Balur } \\
\text { Maath, Motijheel }\end{array}$ & $\begin{array}{l}\mathrm{N} 23^{\circ} 43^{\prime} 23.16^{\prime \prime} \\
\mathrm{E} 90^{\circ} 25^{\prime} 26.82^{\prime \prime}\end{array}$ & $\begin{array}{l}(0.07- \\
0.19)\end{array}$ & 0.132 & 0.038 & $0.231 \pm 0.058$ \\
\hline 22 & Gopibaag Jame Masjid & $\begin{array}{l}\text { N234' } 19.38^{\prime \prime} \\
\text { E90 } 25^{\prime} 36.54^{\prime \prime}\end{array}$ & $\begin{array}{l}(0.12- \\
0.23)\end{array}$ & 0.175 & 0.036 & $0.306 \pm 0.058$ \\
\hline 23 & Gopibaag Railgate & $\begin{array}{l}\text { N234' } 20.34^{\prime \prime} \\
\text { E90'25'38.22”' }\end{array}$ & $\begin{array}{l}(0.07- \\
0.21)\end{array}$ & 0.146 & 0.044 & $0.256 \pm 0.078$ \\
\hline 24 & $\begin{array}{l}\text { Kamalapur Railgate } \\
\text { Near TT Para Slums }\end{array}$ & $\begin{array}{l}\text { N2343'30.24' } \\
\text { E90'25'38.34”' }\end{array}$ & $(0.07-0.2)$ & 0.135 & 0.041 & $0.236 \pm 0.073$ \\
\hline 25 & Khilgaon Rail Gate & 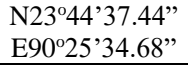 & $\begin{array}{l}(0.05- \\
0.18)\end{array}$ & 0.115 & 0.041 & $0.201 \pm 0.090$ \\
\hline 26 & $\begin{array}{l}\text { Amtola Kendrio Shahi } \\
\text { Masjid, North } \\
\text { Shahjahanpur }\end{array}$ & $\begin{array}{l}\text { N234'ㄱ․․ㅇ' } \\
\text { E90 } 25^{\prime} 26.61^{\prime \prime}\end{array}$ & $\begin{array}{l}(0.09- \\
0.27)\end{array}$ & 0.181 & 0.058 & $0.318 \pm 0.058$ \\
\hline 27 & $\begin{array}{l}\text { Mirza Abbas } \\
\text { Mohila Degree Col- } \\
\text { lege }\end{array}$ & $\begin{array}{l}\text { N234'24.96" } \\
\text { E90'25'21.84”' }\end{array}$ & $\begin{array}{l}(0.11- \\
0.23)\end{array}$ & 0.170 & 0.038 & $0.297 \pm 0.058$ \\
\hline
\end{tabular}

Table 1: Outdoor environmental radiation dose rate and annual effective dose from May-August 2018 at Motijheel Thana in Dhaka city.

Fig. 2 shows the outdoor annual effective dose of each monitoring location was normalized to the minimum annual effective dose. From Fig. 2, it was observed that the difference of annual effective dose of each monitoring location at Motijheel Thana area is not high. The reason for this difference might be geographical characteristics of each location. 


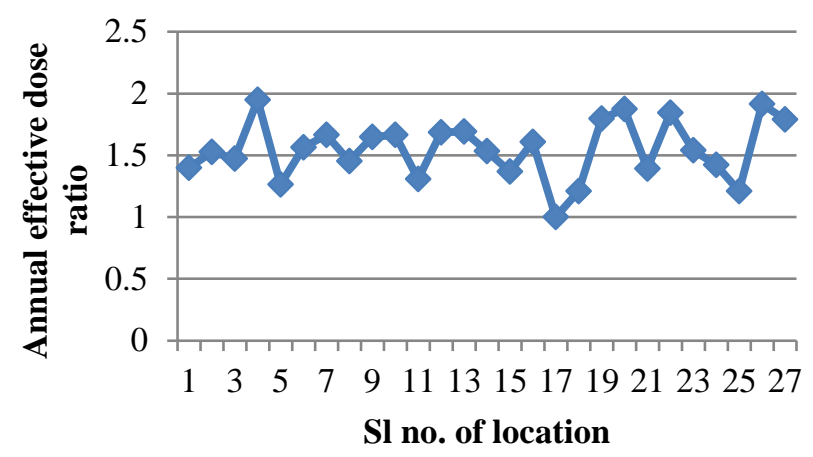

Fig. 2: Outdoor environmental annual effective dose values normalized to the minimum annual effective dose for each location at Motijheel Thana area.

The frequency distribution of the outdoor environmental radiation dose rates in air follows a normal type distribution as shown in Fig. 3. It can be seen from Fig.3 that most of the absorbed dose rate are within the range of 1000-1500 $\mathrm{nSv} / \mathrm{hr}$ at Motijheel Thana area.

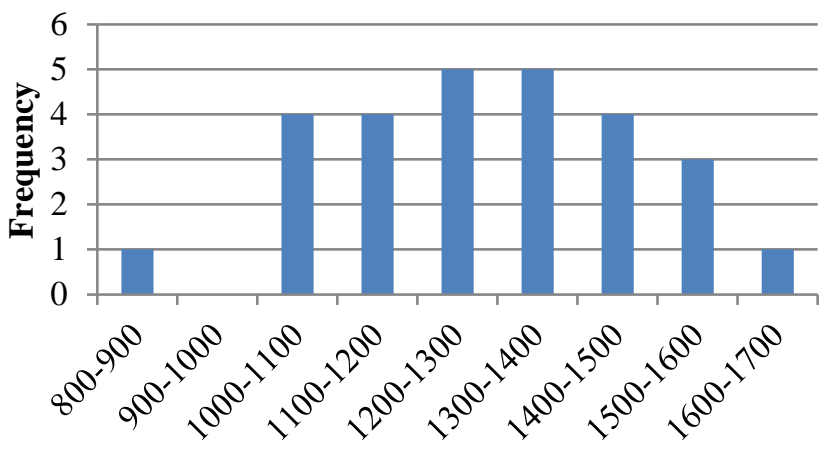

Absorbed dose rate (nSv/hr)

Fig. 3: Frequency distribution of the absorbed dose rates (nSv.h-1) at Motijheel Thana area in Dhaka city

The range of the dose rate, mean and range of the annual effective dose due to the outdoor environmental radiation to the public of Motijhhel Thana in Dhaka city is depicted in Table 2. It can be seen from Table 2 that the range of dose rate and annual effective dose to public of Motijheel Thana is lower than few countries like Indonesia, India, China and higher than those of Islamic Republic of Iran, Azerbaijan, Spain, Czech Republic, Bulgaria and Finland. The proper reason for high radiation dose rates are not known, but might be attributed to geographical, geological, and latitudes/longitudes of the cities studied. The mean annual effective doses to public for countries are mostly ranged from $0.30-0.60 \mathrm{mSv}$ (UNSCEAR, 2008). The annual effective dose to public at Motijheel Thana in Dhaka city ranged from $0.166-0.324 \mathrm{mSv}$ which is within the range of worldwide average value. The mean outdoor environmental radiation dose rate at the Motijheel Thana area was found to be $0.147 \pm 0.047 \mu \mathrm{Sv} \cdot \mathrm{h}^{-1}$ which is almost equal to the Azerbaijan (UNSCEAR, 2008) as shown in Table 2.

The ELCR on public at the outdoor environment of the Motijheel Thana area is ranged from $0.9 \times 10^{-3}$ to $1.7 \times 10^{-3}$ with an average value of $1.3 \times 10^{-3}$, which is higher than the world average value of $0.29 \times 10^{-}$ ${ }^{3}$. The calculation of ELCR on public is based on the annual effective dose. The annual effective dose due to natural radiation varies from location to location because of geological features. The variation of the ELCR on public at 27 locations of the outdoor environment is shown in Fig.4. 


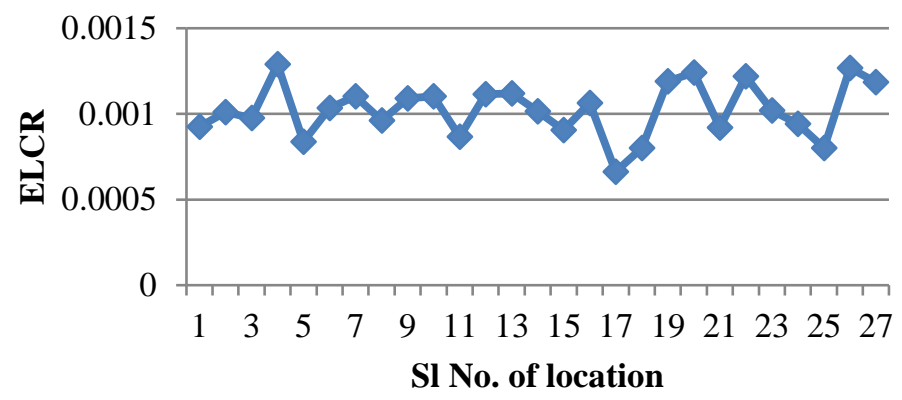

Fig. 4: Excess life-time cancer risk (ELCR) on public at Motijheel Thana area in Dhaka city.

Table 2 Comparison of outdoor environmental radiation dose rate range, mean and annual effective dose range due to natural radiation sources for selected countries (UNSCEAR, 2000) with this study.

\begin{tabular}{|c|c|c|c|}
\hline Country & $\begin{array}{c}\text { Range of } \\
\text { radiation dose } \\
\text { rate }\left(\mu S v \cdot h^{-1}\right)\end{array}$ & $\begin{array}{c}\text { Mean } \\
\text { radiation } \\
\text { dose rate } \\
\left(\mu S v . h^{-1}\right)\end{array}$ & $\begin{array}{c}\text { Range of } \\
\text { annual } \\
\text { effective dose } \\
(\mathrm{mSv})\end{array}$ \\
\hline Finland & $0.077-0.171$ & 0.103 & $0.135-0.300$ \\
\hline Spain & $0.050-0.129$ & 0.085 & $0.088-0.226$ \\
\hline Indonesia (Karimu Island) & $0.200-0.410$ & 0.310 & $0.350-0.718$ \\
\hline Islamic Republic of Iran & $0.036-0.130$ & 0.112 & $0.063-0.228$ \\
\hline India (Odisha) & $0.251-0.879$ & 0.449 & $0.439-1.540$ \\
\hline Czech Republic & $0.006-0.245$ & 0.100 & $0.011-0.429$ \\
\hline China & $0.011-0.523$ & 0.815 & $0.019-0.916$ \\
\hline Bulgaria & $0.075-0.140$ & 0.100 & $0.131-0.245$ \\
\hline Azerbaijan & $0.075-0.205$ & 0.140 & $0.131-0.359$ \\
\hline Italy (Lazio) & $0.120-0.270$ & 0.175 & $0.210-0.473$ \\
\hline This Study & $0.095-0.185$ & 0.147 & $0.166-0.324$ \\
\hline
\end{tabular}

Table 2: Comparison of outdoor environmental radiation dose rate range, mean and annual effective dose range of selected countries

*UNSCEAR, 2000

\section{CONCLUSION}

The mean real-time radiation dose rate at the outdoor environment of the Motijheel Thana area was found to be $0.147 \pm 0.047 \mu \mathrm{Sv} . \mathrm{hr}^{-1}$ which is almost equal to the Azerbaijan. The real-time radiation monitoring is important to generate the baseline database before starting operation of the country's first nuclear power plant. The national baseline database is very important for comparison before and after operation of the nuclear power plant. The real-time radiation monitoring is very essential in and around radiological facilities (hospitals) for the detection of the man-made radionuclides releasing (if any) from the hospitals. From the study, it is observed that the ELCR on public at Motijheel Thana area is higher than that of the worldwide average value of $0.29 \times 10^{-3}$. The higher ELCR on public at Motijheel Thana area is due to the many high-rise buildings are situated in that area. Construction's materials of the buildings are also contributed to public exposures. Many countries have already assessed the distribution of natural radioactivity and finalized the formation of the radiological mapping throughout the country such as USA, Canada, Australia, Switzerland, Slovakia, Slovenia, Czech Republic, and UK, etc. It can be concluded that sufficient training of the manpower on radiation safety and modern equipments to be installed in the radiological facilities (hospitals) for minimizing the unnecessary exposure to public from man-made sources and thereby improving the public health keeping the environment free from radiation hazard.

\section{Acknowledgement}

This research is funded by the Ministry of Science and Technology, Government of Bangladesh under the Special Research Allocation Project 2019-2020 \& 2020-2021 (the grant serial no. 523 MS \& 519 MS). 


\section{REFERENCE}

Al-Ghorable F.H. (2005) "Measurement of environmental terrestrial gamma radiation dose rate in three mountainous locations in the western region of Saudi Arabia", Environ. Res., Vol. 98, pp.160-166.

AL-SALEH F.S. (2007) "Measurements of indoor gamma radiation and radon concentrations in dwellings of Riyadh city, Saudi Arabia", Appl. Radiat. Isot., Vol. 65, pp.843- 848.

Arvela H. (2002) "Population distribution of doses from natural radiation in Finland", Int. Congr. Ser., Vol.1225, pp.9-14.

Ateba J.F.B., Ateba P.O., Ben-Bolie G.H., Abiama P.E., Abega C.R., Mvondo S. (2010) "Natural background dose measurements in south Cameroon", Radiat. Prot. Dosim., Vol. 140, pp.81-88.

ATSDR (1999) “Agency for Toxic Substances and Disease Registry: Toxicological Profile for Ionizing Radiation (Atlanta, GA: US, Department of Health and Human Services, Public Health Service.)

Bangladesh Population Census (2011), Bangladesh Bureau of Statistics, Statistics and Information Division, Ministry of Planning (ISBN-978-984-519-036-7).

Beck H. L., Campo J. D., Gogolak C.(1972) "In-Situ Ge(Li) and NaI(Tl) Gamma-ray Spectrometry”, New York, US DOE, Environmental measurement Lab., HASL-258.

Belivermis M., Kiliç N., Çotuk Y., Topcuoğlu S. (2010) "The effects of physicochemical properties on gamma emitting natural radionuclide levels in the soil profile of Istanbul", Environ. Monitor. Assess., Vol. 163 (1-4), pp.15-26.

Clouvas a., Xanthos S., Antonopoulosdomis M. (2004) "Radiological Maps of Outdoor and Indoor Gamma Dose Rates in Greek Urban Areas Obtained by In Situ Gamma Spectrometry”, Radiation Protection Dosimetry, Vol. 112 (2), pp. 267-275.

Hazrati S., Sadeghi H., Amani M., Alizadeh B., Fakhimi H., Rahimzadeh S. (2010) "Assessment of gamma dose rate in indoor environments in selected districts of Ardabil Province, Northwestern Iran”, Int. J. Occup. Hyg., Vol. 2, pp. 42-45.

http://en.worldstat.info/Asia/Bangladesh, accessed: 10 February 2021.

https://www.banglapedia.org/, accessed: 20 January 2021

ICRP (2007) "Recommendations of the ICRP: Annals of the ICRP (International Commission on Radiological Protection)", Vol. 37, pp.2-4.

NCRP (2009) "National Council on Radiation Protection and Measurements: Ionizing radiation exposure of the population of the United States (NCRP Report No. 160)", (Bethesda, Md:).

Owner's Manual, GARMIN eTrex HC Series, available at https://static.garmincdn.com/pumac/eTrexLegendHCx_OwnersManual.pdf.

QUARTO M. PUGLIESE M., ROCA V. (2013) “Gamma dose rate measurements in dwellings of Campania region, South Italy", Journal of Environmental Radioactivity, Vol.115, pp.114-117.

Rybach L, Bachler D, Bucher B, Schwarz G (2002) "Radiation doses of Swiss population from external sources", J. Environ. Radiat., Vol. 62, pp.277-286.

Sagnatchi F, Salouti M, Eslami A. (2008) "Assessment of annual effective dose due to natural gamma radiation in Zanjan (Iran)”, Radiat. Prot. Dosim., Vol.132, pp.346-349.

Svoukis E., Tsertos H. (2006) "Indoor and outdoor In situ high-resolution gamma radiation measurements in urban area of Cyprus", Department of Physics, University of Cyprus, Nicosia, Cyprus.

Tavakoli M.B. (2003) “Annual background radiation in the city of Isfahan”, Med. Sci. Monit., Vol. 9,pp.7-10.

UNSCEAR (1982) "United Nations Scientific Committee on the Effects of Atomic Radiation. Ionizing radiation: sources and biological effects", United Nations Scientific Committee on the Effects of Atomic Radiation", (New York: United Nations E82. IX.8).

UNSCEAR (1988) "United Nations Scientific Committee on the Effects of Atomic Radiation, sources, effects and risks of ionizing radiation", (United Nations, New York).

UNSCEAR (2000) "United Nations Scientific Committee on the Effects of Atomic Radiation", Sources and Effects of Ionizing Radiation Report to General Assembly, with Scientific Annexes (New York: United Nations, United Nations Sales Publication E.00.IX.3).

UNSCEAR (2008) "United Nations Scientific Committee on the Effects of Atomic Radiation Sources and Effects of Ionizing Radiation", Report to General Assembly with Scientific Annexes, volume I, Annex A: Medical radiation exposures (New York: United Nations, United Nations Publication Sales No.E.10.XI.3).

User Manual Gamma-Scout, available at https://www.gamma-scout.com/EN/Handbuch.php

W. F. Wilson. (1994) “A Guide to Naturally Occurring Radioactive Materials”, Oklahoma, PennWell Books, pp.128. 